J. clin. Path., 1976, 29, 815-823

\title{
Sensitivity of Providence to antiseptics and disinfectants
}

\author{
D. J. STICKLER AND B. THOMAS
}

From the Department of Applied Biology, University of Wales Institute of Science and Technology, Cathays Park, Cardiff

SYNOPSIS Seventy isolates of Providence were obtained from urinary tract infections in patients from five hospitals. They were all identified as Providence B (Providencia stuartii). A typing system was devised for these organisms based on their production of and sensitivity to bacteriophage and bacteriocins. Using this system, 27 distinct strains were recognized, and it was clear that many patients had been infected with the same strain. The minimum inhibitory concentrations of six antiseptics and disinfectants for these strains were determined. Many of the strains were up to 300-fold more resistant to the cationic antiseptics chlorhexidine, cetrimide, and Resiguard than the control strain Escherichia coli NCTC 10418. The sensitivities of the Providence strains to Hycolin, glutaraldehyde, and phenyl mercuric nitrate, however, were similar to those of the control organism. There were significant correlations between the sensitivities of the strains to the three cationic antiseptics. The loss of chlorhexidine resistance from a Providence strain after exposure of the cells to $N$ methyl- $N^{\prime}$ nitro $N$ nitrosoguanidine resulted in a concomitant loss of resistance to cetrimide and Resiguard, but there was no significant increase in the sensitivity of the mutants to the other three antibacterials.

The main clinical importance of the Providence group of bacteria stems from their capacity to produce urinary tract infections, especially in patients having some underlying urological problem. Dutton and Ralston (1957), for example, found that $21 \%$ of infections in an urological ward, occurring after insertion of an indwelling catheter into the bladder or other instrumentation of the urinary tract, were caused by Providence. Milner (1963) reported that Providence was responsible for $38 \%$ of urinary tract infections in paraplegic patients whose bladder management involved either intermittent or indwelling catheterization. Similar findings have been reported by Fields et al (1967), Li and Miller (1970), Solberg and Matsen (1971), and Dobrey (1971).

Hospital isolates of Providence are well known to be resistant to a wide range of antibiotics (Middleton, 1958; Tomaschoff, 1969; Dobrey, 1971; Graevenitz and Nourbakhsh, 1972), and $\mathrm{Li}$ and Miller (1970) have suggested that this property of multiple antibiotic resistance could well favour the increasing significance of this organism as an agent of infection

Received for publication 12 February 1976 in the hospital environment. The particular situation that the organism seems to favour, the urinary tract that is undergoing instrumentation, is one where it is likely to be exposed to antiseptics (Gillespie et al, 1967; Desautels, 1969; Stickler et al, 1971). It would therefore be of considerable ecological advantage to this organism to have a degree of resistance to such antibacterial agents. In this connection O'Flynn and Stickler (1972) reported that some strains of Providence isolated from the urethral meatuses of paraplegic patients undergoing intermittent catheterization of the bladder by a procedure which involved the application of chlorhexidine to the external genitalia, could grow in the presence of $200 \mu \mathrm{g} / \mathrm{ml}$ of the antiseptic, a level well above that of $10-50 \mu \mathrm{g} / \mathrm{ml}$ of the agent normally considered to inhibit Gram-negative bacteria (Davies et al, 1954).

In view of the clinical significance of these organisms at sites where conventionally antiseptics play an important role in the prevention of infection, it is surprising that there is so little information in the literature on the sensitivity of Providence to antiseptics and disinfectants. The object of this study was to make a collection of isolates of Providence from a 815 
number of hospitals and to test their sensitivity to a range of these agents.

\section{Material and methods}

\section{STRAINS USED}

The clinical isolates of Providence used in this study were all isolated from urinary tract infections, the 70 isolates coming from 70 patients in five hospitals. Seven of the isolates were obtained from paraplegic patients undergoing intermittent catheterization of the bladder at the National Medical Rehabilitation Centre, Our Lady of Lourdes Hospital, Dublin; 14 were obtained from $\mathrm{Dr}$ C. Keane, of the Adelaide Hospital, Dublin, and were from urinary infections in patients having indwelling bladder catheters. A total of $\mathbf{4 8}$ of the isolates came from three Cardiff hospitals, 25 of these coming from a paraplegic unit and most of the balance from gynaecological wards. The NCTC strains 2481, 6344, 10286, and 10318 were used as reference organisms. In some experiments Escherichia coli NCTC 10418 and Proteus mirabilis NCIB 60 were used as control organisms. The clinical isolates were identified as Providence using the methods of Cowan and Steel (1965).

\section{TYPING OF THE PROVIDENCE ISOLATES}

The Providence isolates were typed using a method similar to that devised by Farmer and Herman (1969) for the typing of Pseudomonas aeruginosa. It involved the characterization of strains by (a) their sensitivity to a set of bacteriophage and bacteriocin preparations, and $(b)$ the host range of the bacteriocin or bacteriophage produced by each strain. In order to produce preparations of phage and bacteriocins for typing, cultures of each of the isolates were grown to early log phase in broth
(Oxoid No. 2 nutrient broth) at $37^{\circ}$ with aeration i⿺辶 a shaking waterbath. They were then induced wit mitomycin-c (1-10 $\mu \mathrm{g} / \mathrm{ml})$ (Otsuji et al, 1959). The cultures generally lysed after $1 \frac{1}{2}$ to 2 hours. BacteriaP debris was removed by centrifugation at $3000 \mathrm{~g}$ fo? 15 minutes and the supernatant fluid, containing the phage or bacteriocin, was stored at $4^{\circ}$ before use. In order to demonstrate the phage or bacterioci⿱ activity on the Providence isolates, inocula (0.5 m from 18-hour broth cultures of each isolate were: added to aliquots $(4 \mathrm{ml})$ of molten nutrient agar (Oxoid Ltd) at $45^{\circ}$ and then poured as a top laye $\overrightarrow{\mathrm{C}}$ onto nutrient agar plates. Standard drops of the phage and bacteriocin preparations were the spotted onto these top layers using a multi-applicatoig similar to that designed by Tarr (1958). The plates were incubated overnight at $37^{\circ}$ and examined fopo plaques or zones of bacteriocin activity.

\section{MINIMUM INHIBITORY CONCENTRATION} DETERMINATIONS

The strains to be tested were grown for 24 hours $\frac{\mathbb{D}}{a}$ $37^{\circ}$ in broth. Volumes $(5 \mu \mathrm{l})$ of a $10^{-4}$ dilution, eaç containing approximately $10^{3}$ viable cells, were the dropped, using the multi-applicator, onto the surface of nutrient agar plates containing a rangerof doubling dilutions of antibacterial agents (table I standard method was adopted for the preparation of the plates. The antibacterial agents were addectie molten nutrient agar that had been allowed to coof to $50^{\circ}$. The plates were dried at $37^{\circ}$ for 20 minutes and then used directly. After inoculation the plate were incubated at $37^{\circ}$ and examined for growt after 24 hours. The lowest concentration of the agen? that prevented colony formation was taken as the minimum inhibitory concentration (MIC) for the strain. The tests were performed in duplicate, $E .{ }^{\circ}$ colli.

\begin{tabular}{|c|c|c|}
\hline Agent & Source & $\begin{array}{l}\text { Concentrations incorporated into nutrient agar for } \\
\text { MIC testing }\end{array}$ \\
\hline Chlorhexidine & $\begin{array}{l}\text { A } 5 \% \mathrm{w} / \mathrm{v} \text { solution of Hibitane (chlorhexidine } \\
\text { digluconate) ICI Ltd }\end{array}$ & $\begin{array}{l}\text { Various volumes of this concentrate were added to } \\
\text { agar }(5-1600 \mu \mathrm{g} / \mathrm{ml})\end{array}$ \\
\hline Cetrimide & Cetavlon, ICI Ltd & $\begin{array}{l}\text { A stock solution }(100 \mathrm{mg} / \mathrm{ml}) \text { in distilled water was } \\
\text { used to prepare plates containing } 25-1600 \mu \mathrm{g} / \mathrm{ml}\end{array}$ \\
\hline Glutaraldehyde & Sigma Ltd & $\begin{array}{l}\text { A stock solution }(10 \% \mathrm{w} / \mathrm{v}) \text { in } 0.3 \% \mathrm{w} / \mathrm{v} \text { sodium } \\
\text { bicarbonate was used to prepare plates containing } \\
100-1600 \mu \mathrm{g} / \mathrm{ml}\end{array}$ \\
\hline Resiguard & $\begin{array}{l}\text { The commercial concentrate (Nicholas Laboratories } \\
\text { Ltd) containing picloxydine digluconate } 1 \cdot 0 \% \text {, } \\
\text { octylphenoxy polyethoxyethanol } 11 \cdot 0 \% \\
\text { benzalkonium chloride } 12.0 \%\end{array}$ & $\begin{array}{l}\text { Various volumes of the commercial concentrate were } \\
\text { added directly to molten agar to produce dilutions of } \\
1 / 100 \text { to } 1 / 3200 \text { of Resiguard }\end{array}$ \\
\hline Hycolin & $\begin{array}{l}\text { The commercial concentrate (William Peason Ltd, } \\
\text { Clough Hill, Hull) containing a combination of } \\
\text { synthetic phenols }\end{array}$ & $\begin{array}{l}\text { A } 10 \% \mathrm{v} / \mathrm{v} \text { solution of concentrate in distilled water } \\
\text { was used to prepare agar containing } 0.01 \text { to } 0.16 \% \\
\mathrm{v} / \mathrm{v} \text { of commercial concentrate }\end{array}$ \\
\hline Phenyl Mercuric Nitrate & BDH Ltd & $\begin{array}{l}\text { A stock solution, } 100 \mu \mathrm{g} / \mathrm{ml} \text { in distilled water, was } \\
\text { used to prepare agar containing } 0 \cdot 125 \text { to } 2 \mu \mathrm{g} / \mathrm{ml}\end{array}$ \\
\hline
\end{tabular}


10418 and $P$. mirabilis 61 (Stickler, 1974) being included as reference control organisms with each batch of strains tested.

\section{BACTERICIDAL EFFECT OF ANTISEPTICS ON PROVIDENCE}

The bactericidal effect of six antiseptics was tested by performing log reduction experiments on selected strains of Providence, E. coli 10418, and P. mirabilis 60 . The organisms were grown for $\mathbf{1 8}$ hours in broth culture, and $0.5 \mathrm{ml}$ volumes were mixed with solutions of the various antibacterials in distilled water $(4.5 \mathrm{ml})$. The cells were exposed to the agents for 10 minutes at ambient temperatures, and then $0.5 \mathrm{ml}$ samples were withdrawn and added to $4.5 \mathrm{ml}$ of the appropriate neutralizer (Kelsey and Maurer, 1972; Russell, 1974). After 10 minutes in the neutralizer further dilutions were made in nutrient broth in order to perform viable counts on the survivors. Viable counts were also performed on the cultures used as a source of inocula for these tests. From the number of cells added to the antiseptic and the number surviving the 10 minute exposure the $\log _{10}$ of the reduction in viable count was calculated. The antibacterial agents and neutralizers used in this experiment are shown in table II.

\section{ANTIBIOTIC SENSITIVITY}

The antibiotic sensitivity patterns of the Providence strain were determined by seeding plates of DST agar (Oxoid Ltd) with young log phase broth cultures and applying U3 Multodiscs (Oxoid Ltd), which are impregnated with the following antibiotics: gentamicin $(10 \mu \mathrm{g})$, colistin $(10 \mu \mathrm{g})$, nitrofurantoin (200 $\mu \mathrm{g})$, sulphafurazole $(500 \mu \mathrm{g})$, kanamycin $(30 \mu \mathrm{g})$, ampicillin $(25 \mu \mathrm{g})$, sulphamethoxazole/trimethoprim $(25 \mu \mathrm{g})$, and tetracycline $(50 \mu \mathrm{g})$. E. coli 10418

\begin{tabular}{|c|c|}
\hline Agent & Neutralizer \\
\hline $\begin{array}{l}\text { Chlorhexidine } 5 \% \text { Hibitane } \\
\text { (ICI Ltd) }\end{array}$ & $\begin{array}{l}\text { Nutrient broth (Oxoid Ltd) } \\
\text { containing } 3 \% \text { lecithin and } 10 \% \\
\text { Tween } 80\end{array}$ \\
\hline $\begin{array}{l}\text { Benzalkonium chloride } \\
\text { (Winthrop Laboratories Ltd) }\end{array}$ & " \\
\hline Resiguard (Nicholas Ltd) & " \\
\hline $\begin{array}{l}\text { Hycolin (William Peason Ltd) } \\
\text { Betadine (Napp Laboratories } \\
\text { Ltd) } \\
\text { Commercial concentrate } \\
10 \% \text { povidone-iodine containing } \\
1 \% \text { available iodine }\end{array}$ & $\begin{array}{l}\text { Nutrient broth containing } \\
0.5 \% \text { sodium thiosulphate }\end{array}$ \\
\hline $\begin{array}{l}\text { Hypochlorite, a commercial } \\
\text { concentrate Milton } \\
\text { (Richardson-Merrell Ltd) } \\
\text { containing } 1 \% \mathrm{w} / \mathrm{v} \text { sodium } \\
\text { hypochlorite and } 16 \% \mathrm{w} / \mathrm{v} \mathrm{NaCl}\end{array}$ & $"$ \\
\hline
\end{tabular}

Table II Antibacterial agents and neutralizers used in log reduction experiments was used as a sensitive control with each batch of strains tested.

ISOLATION OF CHLORHEXIDINE-SENSITIVE MUTANTS

Chlorhexidine-sensitive mutants of Providence strain 66 were isolated using the mutagen $N$-methyl- $N^{\prime}$ nitro $N$ nitrosoguanidine (NTG) (Sigma Chemical Co Ltd), according to the procedure of Adelberg $e t$ al (1965). A log phase culture of Providence 66 was harvested by centrifugation, and the cells were washed in $0.05 \mathrm{M}$ phosphate buffer ( $\mathrm{pH} \mathrm{6.0)}$ ) and then resuspended in the buffer at a density of about $2 \times 10^{8} \mathrm{cells} / \mathrm{ml}$. NTG was added to a final concentration of $50 \mu \mathrm{g} / \mathrm{ml}$, and the culture was shaken at $37^{\circ}$ for 30 minutes. The cells were then washed and resuspended in buffer and finally plated for single colonies on nutrient agar. After incubation at $37^{\circ}$ for 18 hours the colonies were replica plated using velvet pads onto nutrient agar containing chlorhexidine $(50 \mu \mathrm{g} / \mathrm{ml})$. Colonies which failed to replicate on this medium were picked off and re-examined for their sensitivity to chlorhexidine. Approximately 4000 colonies were screened in this way and a total of eight sensitive clones was isolated. These sensitive mutants were confirmed as derivatives of the parent strain 66 by the typing procedure.

\section{Results}

TYPING OF PROVIDENCE ISOLATES

A total of 70 isolates of Providence were obtained from five hospitals and all were identified as Providence B (Cowan and Steel, 1965). Providencia stuartii (Edwards and Ewing, 1972), as they produced acid from inositol and failed to produce gas from glucose. All 70 of the isolates together with four NCTC strains were induced with mitomycin-c. Sixty-nine of the 74 cultures tested lysed approximately 2 hours after induction and produced high titres of phage or bacteriocin. These preparations were then used to type the isolates. Table III is an abbreviated summary of the results of this typing, showing the results with respect to 58 of the clinical isolates. Examination of the table will show that all the strains listed produce an interaction of some sort and that 23 distinct patterns of sensitivity and activity were recorded, indicating the presence of at least 23 distinct strains. When all results from the 70 isolates were examined, 26 distinct patterns of sensitivity and activity were recorded among the clinical isolates. Four isolates, which are not included in table III, produced no interaction, and while it is possible that these could represent four different strains, they could also be repeated isolates of the same strain. Only one of these untypable isolates 


\begin{tabular}{|c|c|c|c|c|c|c|c|c|c|c|c|c|c|c|c|c|c|c|c|c|c|c|c|c|c|c|c|}
\hline \multirow{2}{*}{\multicolumn{2}{|c|}{$\begin{array}{l}\text { Source and strain number } \\
\text { of indicator lawns }\end{array}$}} & \multicolumn{25}{|c|}{ Bacteriophage or bacteriocin preparations obtained from numbered strains of Providence } & \multirow[t]{2}{*}{ 产 } \\
\hline & & 23 & 59 & 7 & 8 & 18 & 2 & 6 & 26 & 71 & 3 & 27 & 34 & 35 & 66 & 68 & 74 & 75 & 77 & 84 & 87 & 88 & 90 & 95 & 101 & 10 & \\
\hline Dublin & $23(5)^{1}$ & - & - & - & - & + & - & + & - & - & + & - & - & + & - & + & - & - & - & - & - & - & + & - & - & - & \\
\hline Hosp. 1 & 59 (1) & - & - & - & - & + & - & - & - & - & - & - & - & + & - & + & - & - & - & - & - & - & - & - & - & - & \\
\hline \multirow{3}{*}{$\begin{array}{l}\text { Dublin } \\
\text { Hosp. } 2\end{array}$} & 7 (12) & - & - & - & - & $T$ & - & $T$ & - & - & + & - & - & + & - & + & - & - & - & - & - & - & $T$ & - & - & - & \\
\hline & 8 (1) & - & - & - & - & + & - & - & - & - & + & - & - & - & - & - & - & - & - & - & - & - & - & - & - & - & $\overline{\bar{\omega}}$ \\
\hline & 18 (1) & - & - & - & - & - & - & + & - & - & - & - & - & - & - & - & - & - & - & - & - & - & - & - & - & - & \\
\hline \multirow{4}{*}{$\begin{array}{l}\text { Cardiff } \\
\text { Hosp. } 1\end{array}$} & $2(1)$ & + & + & + & + & + & - & + & - & - & + & - & - & + & - & + & - & - & - & - & + & - & + & - & + & + & \\
\hline & $6(1)$ & - & - & - & - & - & - & - & - & - & - & - & - & - & - & - & - & - & - & - & - & - & - & - & - & - & ుָم \\
\hline & 26 (1) & - & - & - & - & - & - & - & - & - & - & - & - & + & - & + & - & - & - & - & + & - & $T$ & - & - & - & \\
\hline & $71(2)$ & - & - & - & - & - & - & - & - & - & - & - & - & - & - & - & - & - & - & - & - & - & - & - & - & - & \\
\hline \multirow{9}{*}{$\begin{array}{l}\text { Cardiff } \\
\text { Hosp. } 2\end{array}$} & $3(2)$ & - & - & - & - & - & - & - & - & - & - & - & - & - & - & - & - & - & - & - & - & - & - & - & - & - & \\
\hline & 27 (1) & - & - & - & - & - & - & - & - & - & - & - & - & - & - & + & - & - & - & - & - & - & + & - & - & - & \\
\hline & 34 (1) & - & - & - & - & - & - & - & - & - & - & - & - & + & - & - & - & - & - & - & + & - & - & - & - & - & \\
\hline & $35(2)$ & - & - & - & - & - & - & - & - & - & - & - & - & - & - & - & - & - & - & - & - & - & - & - & - & - & \\
\hline & 66 (1) & + & 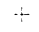 & + & + & + & - & + & - & - & + & - & - & + & - & + & - & - & - & - & + & - & + & - & + & + & \\
\hline & $68(3)$ & - & - & - & - & - & - & - & - & - & - & - & - & - & - & - & - & - & - & - & - & - & - & - & - & - & \\
\hline & 74 (1) & - & - & - & - & - & - & - & - & - & - & - & - & - & - & - & - & - & - & - & - & - & - & - & - & - & \\
\hline & 75 (1) & - & - & - & - & -- & - & - & - & - & + & - & - & - & - & $\therefore$ & - & - & - & - & - & - & - & - & - & - & 6 \\
\hline & 77 (1) & - & $T$ & - & - & - & - & - & - & - & $\div$ & - & - & + & - & + & - & - & - & - & - & - & .. & - & $\div$ & + & $\infty$ \\
\hline \multirow{7}{*}{$\begin{array}{l}\text { Cardiff } \\
\text { Hosp. } 3\end{array}$} & $84(1$ & $\div$ & $\div$ & $\div$ & + & + & - & - & - & + & + & - & - & + & - & $-t$ & + & - & + & - & - & - & + & - & + & $\therefore$ & \\
\hline & 87 (1) & - & - & - & - & - & - & - & - & - & - & - & - & - & - & - & - & - & - & - & - & - & - & - & - & - & \\
\hline & 88 (1) & - & - & - & - & + & + & - & - & - & + & - & - & + & - & + & - & - & - & - & - & - & - & - & - & - & \\
\hline & 90 (14) & - & - & - & - & - & - & - & - & - & - & - & - & - & - & - & - & - & - & - & - & - & - & - & - & - & $\rightarrow$ \\
\hline & 95 (1) & + & + & + & + & + & - & + & - & - & - & - & - & $\div$ & - & $\therefore$ & - & - & - & - & + & - & + & - & + & + & \\
\hline & 101( & + & + & + & + & + & - & - & - & - & - & + & + & + & - & + & + & + & + & - & - & + & $\div$ & + & - & - & \\
\hline & 103 (1) & - & - & - & - & - & - & - & - & - & - & - & - & - & - & - & - & - & - & - & - & - & - & - & - & - & \\
\hline
\end{tabular}

Table III Bacteriophage and bacteriocin typing of 58 of the 70 clinical isolates of Providence

${ }^{1}$ The figure in brackets indicates the number of isolates giving the identical pattern to that shown for the numbered strain.

+ Indicates activity of the phage or bacteriocin produced by the designated strain on the lawn of indicator; - indicates no activity.

was taken for further study as the possible repeated use of MIC data from the same strain could introduce a bias into the calculation of the Spearman and Kendal rank correlation coefficients. The results of this typing therefore indicate that the clinical isolates obtained from the five hospitals represented at least 27 distinct strains.

\section{SENSITIVITY OF STRAINS TO ANTISEPTICS}

MIC determinations were performed on cultures of the 27 clinical strains together with the four NCTC strains and the control organisms E. coli 10418 and $P$. mirabilis 61. Summaries of these results are shown in figures 1 and 2. Inspection of the MIC values obtained for the 31 strains of Providence seemed to indicate that resistance to chlorhexidine was associated with resistance to the other cationic agents. Fig. 3, for example, shows the results of plotting the MIC of Resiguard for each strain against their MICs for $(a)$ cetrimide, and $(b)$ Hycolin. The possibility of significant correlations between sensitivities of the strains to the six antibacterials was examined using non-parametric correlation tests. The strains were ranked on the basis of their MIC values to the various disinfectants, and Kendal and Spearman correlation coefficients were calculated between all possible pairs of rankings using the computer Statistical Package for the Social
Sciences (Nie et al, 1970). The results of such analysis are shown in table IV.

In a further series of experiments the bactericidalo activity of disinfectants was tested against fourd strains of Providence designated as chlorhexidine $\underset{\Rightarrow}{\Rightarrow}$ resistant on the basis of their MICs, each strain $\frac{3}{3}$ having a distinct typing pattern and coming from $\mathrm{a}_{\supset}$ different hospital. Two chlorhexidine sensitive

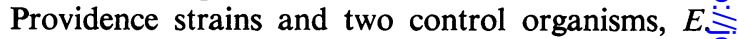
coli 10418 and $P$. mirabilis NCIB 60, were also ex-Oㅇㅇㅇ amined. In these tests the $\log _{10}$ of the reduction in viable count occurring on exposure of each strain to the disinfectant for 10 minutes was determined. Theo concentrations of the agents were chosen so as to produce about a 2-3 log reduction in counts of the sensitive strains. In the cases of the cationic anti- $>$ septics, however, higher concentrations than this had to be used in order to register any significant killing of strains $5,8,66$, and 95 . The eight strains ${ }^{\circ}$ were tested as a batch against each antiseptic in turn. $N$ Table V shows the mean of three log reduction values $N$ obtained for each strain against each antibacterialo agent.

OBSERVATIONS ON CHLORHEXIDINE-SENSITIVE? MUTANTS OF PROVIDENCE

A total of eight chlorhexidine-sensitive mutants were isolated from Providence strain 66 after treat- $\mathbb{D}$ 

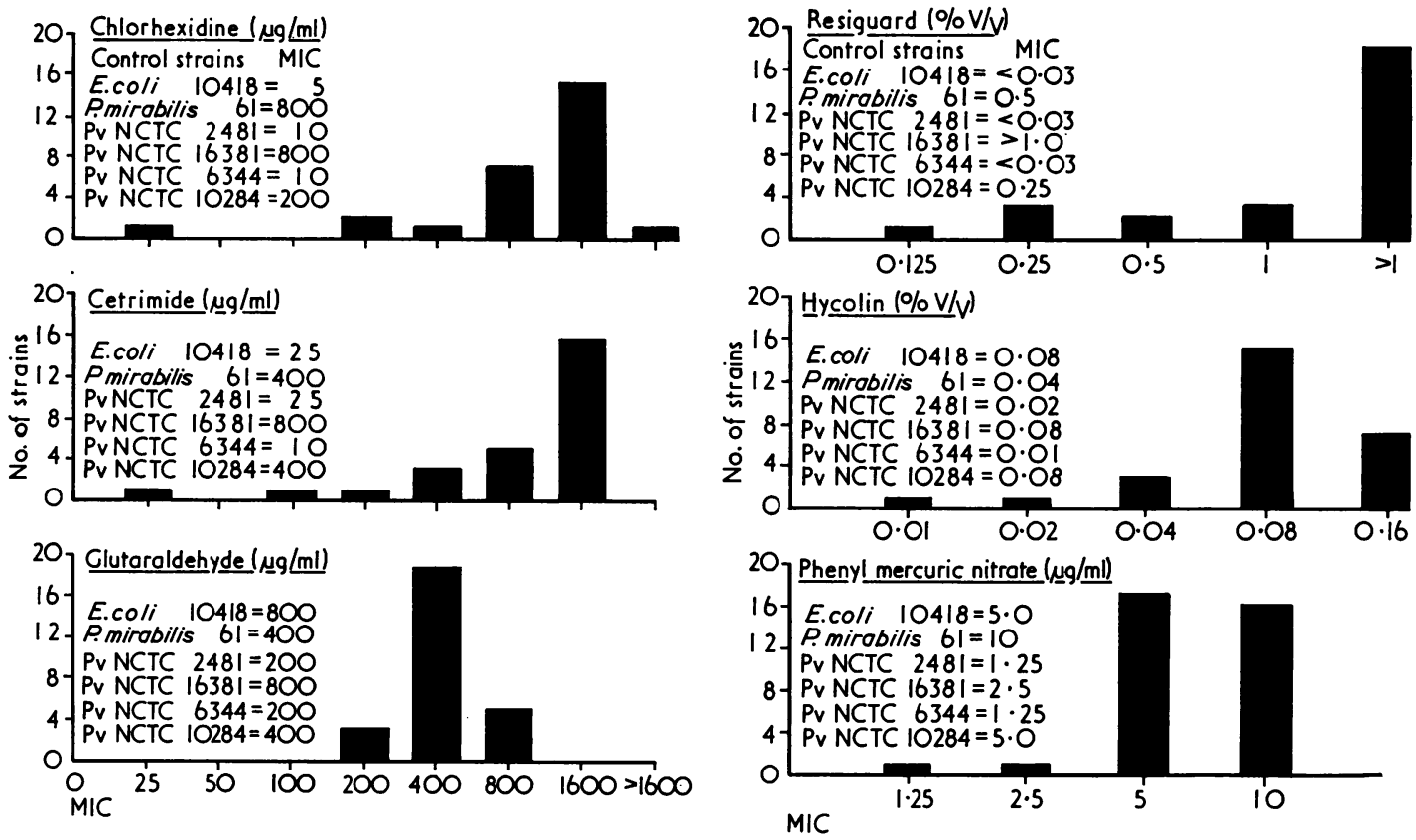

Fig 1 Sensitivity of clinical isolates of Providence to the antibacterials chlorhexidine, cetrimide, and glutaraldehyde.

Fig 2 Sensitivity of clinical isolates of Providence to the antibacterials Resiguard, Hycolin, and phenyl mercuric nitrate.

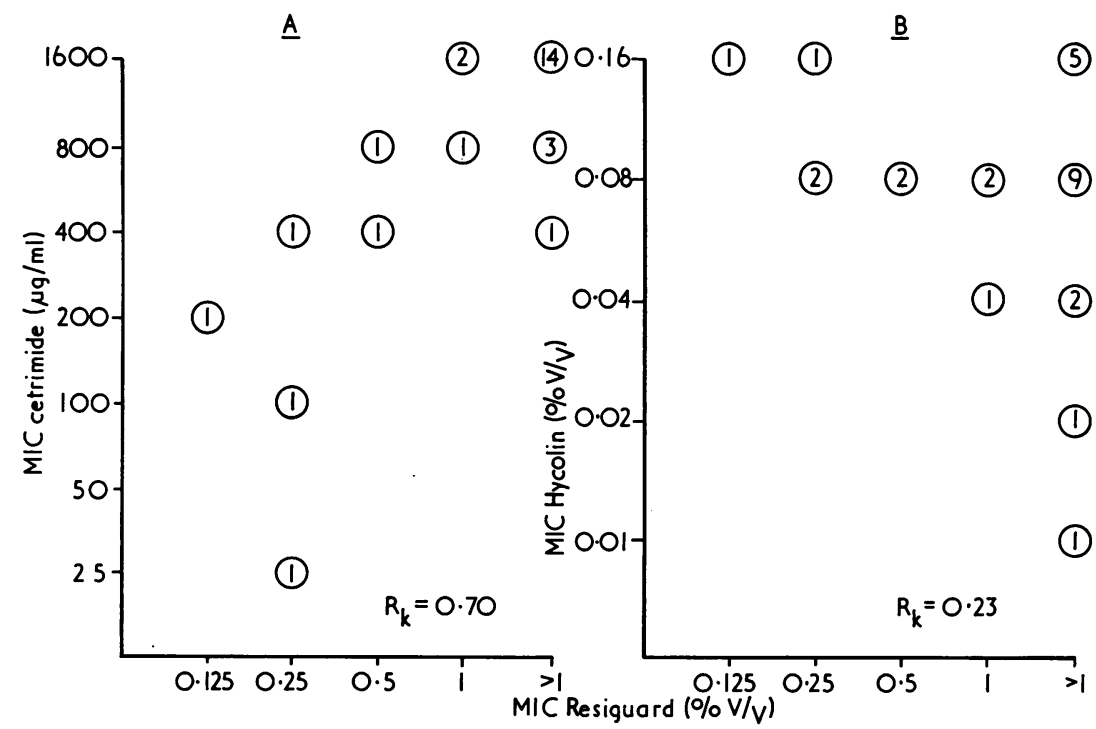

Fig $3 A$ comparison of the sensitivity of Providence strains to $(A)$ Resiguard and cetrimide and $(B)$ Resiguard and Hycolin. The figures in the open circles represent the number of strains having that level of resistance (the scales are $\log _{2}$ of $M I C$ values). $R_{K}$ refers to the Kendal rank correlation coefficient. 


\begin{tabular}{|c|c|c|c|c|c|c|c|c|c|c|c|c|c|c|}
\hline & & \multicolumn{12}{|c|}{ Kendal's rank correlation coefficient } & \\
\hline & & \multicolumn{2}{|c|}{ Chlorhexidine } & \multicolumn{2}{|c|}{ Cetrimide } & \multicolumn{2}{|c|}{ Resiguard } & \multicolumn{2}{|c|}{ Glutaraldehyde } & \multicolumn{2}{|c|}{ Hycolin } & \multicolumn{2}{|c|}{$\begin{array}{l}\text { Phenyl mercuric } \\
\text { nitrate }\end{array}$} & 3 \\
\hline $\begin{array}{l}\text { Spearman's } \\
\text { rank correlation } \\
\text { coefficient }\end{array}$ & $\begin{array}{l}\text { Chlorhexidine } \\
\text { Cetrimide } \\
\text { Resiguard } \\
\text { Glutaraldehyde } \\
\text { Hycolin } \\
\text { Phenyl mercuric } \\
\text { nitrate }\end{array}$ & $\begin{array}{c}\overline{0.71^{1}} \\
0.68^{1} \\
0.20 \\
0.17 \\
-0.11\end{array}$ & $\begin{array}{l}(-\rightarrow) \\
\left(0 \cdot 69^{1}\right) \\
\left(0 \cdot 57^{11}\right) \\
(0 \cdot 20) \\
(0 \cdot 21) \\
(0 \cdot 40)\end{array}$ & $\begin{array}{l}0.64^{1} \\
0.76^{1} \\
0.05 \\
0.07 \\
0.06\end{array}$ & $\begin{array}{l}\left(0.64^{1}\right) \\
(-) \\
\left(0.74^{1}\right) \\
(0.06) \\
(0.28) \\
\\
(0.42)\end{array}$ & $\begin{array}{l}0.62^{1} \\
0.70^{1} \\
-0.18 \\
0.12 \\
0.04\end{array}$ & $\begin{array}{l}\left(0.52^{1}\right) \\
\left(0.68^{1}\right) \\
(-) \\
(-0.01) \\
(0.20) \\
(0.29)\end{array}$ & $\begin{array}{l}0.17 \\
0.04 \\
0.15 \\
- \\
0.81^{1} \\
0.36\end{array}$ & $\begin{array}{l}(0.18) \\
(0.05) \\
(0.01) \\
(-) \\
(0.39) \\
(0.40)\end{array}$ & $\begin{array}{l}0 \cdot 15 \\
0.05 \\
0 \cdot 10 \\
0 \cdot 77^{1} \\
- \\
0.56^{1}\end{array}$ & $\begin{array}{l}(0.18) \\
(0.24) \\
(0.18) \\
(0.36) \\
(-) \\
\left(0.58^{1}\right)\end{array}$ & $\begin{array}{r}-0.11 \\
0.04 \\
0.03 \\
0.32 \\
0.51^{1} \\
\\
-\end{array}$ & $\begin{array}{l}(0.35) \\
(0.36) \\
(0 \cdot 26) \\
(0.37) \\
\left(0.53^{1}\right) \\
(-)\end{array}$ & 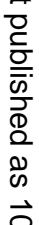 \\
\hline
\end{tabular}

Table IV Kendal and Spearman rank correlation coefficients between sensitivities of Providence to pairs of antiseptics $\overrightarrow{\vec{H}}$ IIndicates that these correlations are highly significant $(P<0.001)$.

The values in brackets were obtained when the MIC screening was repeated on a separate occasion.

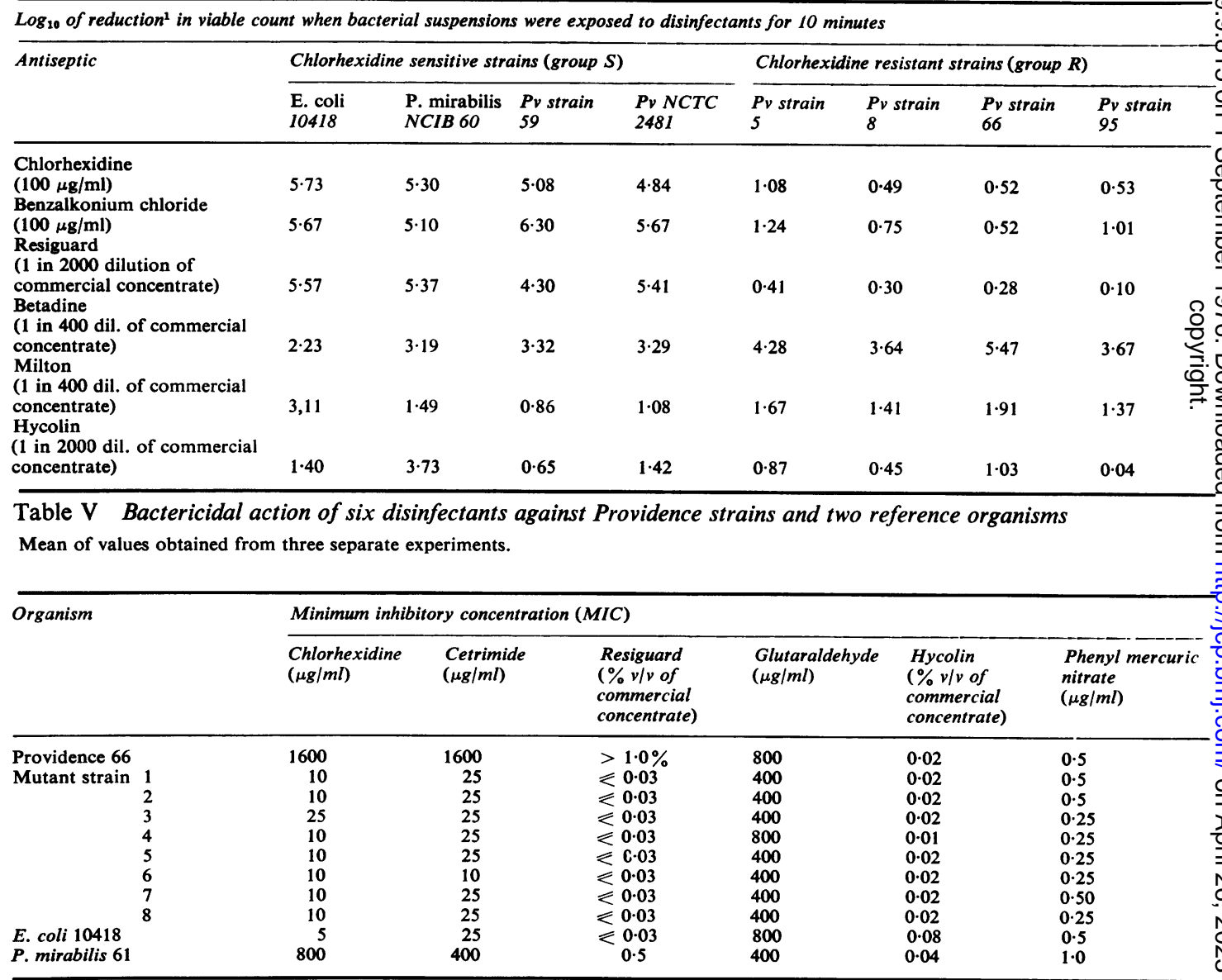

Table VI Sensitivity of Providence strain 66 and its mutants to six antiseptics

ment with NTG. These mutants were subjected to typing and gave the pattern of reactions characteristic of strain 66 , indicating that they were derivatives of the parent strain. They were then examined for their MICs to the six antibacterial agents showne in table I; $E$. coli 10418, $P$. mirabilis strain 61, and Providence strain 66 were included in these tests. The results presented in table VI show that the loss of 
resistance to chlorhexidine has been accompanied by concomitant increase in sensitivity to cetrimide and Resiguard. The mutants were not, however, markedly more sensitive to phenyl mercuric nitrate, glutaraldehyde or Hycolin than the parent strain.

\section{Discussion}

All 70 isolates of Providence used in this work proved to be Providence B (Providencia stuartii). In fact during the collection of specimens two isolates of Providence A (Providencia alcalifaciens) were also obtained but these were not reported on in this study. Many of the earlier studies on the incidence of Providence infections did not distinguish between these two species. Dobrey (1971), however, reported that $\mathbf{1 4 0}$ isolates collected from 48 different patients in a Canadian hospital all proved to be Providence B. Solberg and Matsen (1971) observed that 34 of 45 Providence strains isolated mainly from urinary tract infections, but also from postoperative wound infections in a Minnesota Medical Centre, were type B. Overturf et al (1974) examined 114 isolates, 94 coming from 73 patients in a burns unit of a California hospital and the balance from other hospital services, and found that 102 were Providencia stuartii. These authors also found that strains characterized as Providencia alcalifaciens were susceptible to most antibiotics, whereas Providencia stuartii demonstrated marked antibiotic resistance, a finding that had been previously recorded by Middleton (1958). The results presented in table VII show that the strains isolated in this study are multiply antibiotic resistant.

Dutton and Ralston (1957) reported that a single biochemical type of Providence was isolated from 17 of their patients with urinary tract infections. Milner (1963) similarly found that 38 strains from urinary infections in paraplegic patients belonged to biotype 27 (Ewing et al, 1954) and considered that this finding favoured the theory that infections of the urinary tract with this organism are nosocomial rather than autogenous infections from the patient's own bowel flora. Solberg and Matsen (1971) used biochemical and serotyping for Pro-

\begin{tabular}{lllllllll}
\hline $\begin{array}{l}\text { No. of } \\
\text { strains tested }\end{array}$ & \multicolumn{7}{l}{ No. resistant to each antibiotic } \\
\cline { 2 - 9 } & $C N$ & $C T$ & $F$ & $G$ & $K$ & $P n$ & $S X T$ & $T e$ \\
\hline 27 & 22 & 27 & 23 & 24 & 8 & 23 & 23 & 27 \\
\hline
\end{tabular}

Table VII Antibiotic sensitivity of Providence isolates

$\mathrm{CN}=$ gentamicin, $\mathbf{C T}=$ colistin, $\mathbf{F}=$ nitrofurantoin, $\mathbf{G}=$ sulphafurazole, $\mathbf{K}=$ kanamycin, $\mathbf{P n}=$ ampicillin, $\mathbf{S X T}=$ sulphamethoxazole/trimethoprin, $\mathrm{Te}=$ tetracycline. vidence infections and found that usually two or three patients were infected with strains of the same biotype at the same time and suggest that this again is strong evidence for the nosocomial nature of many infections. The bacteriophage/bacteriocin typing of strains performed in this study would seem to support these views. Examination of table III shows that strains 23 and 7, isolated from the Dublin hospitals, exhibit the same pattern of sensitivity to six different phage/bacteriocin preparations and further that the phage/bacteriocins produced by these strains had identical patterns of activity against lawns of five of the other strains. This evidence indicates that in the Dublin hospitals 17 of the 20 patients were infected with the same strain of Providence. In two of the Cardiff hospitals the isolation of any one strain from two or more patients occurred much less frequently. In the paraplegic unit of the third Cardiff hospital, however, 14 patients were found to be infected with the same bacteriophage/bacteriocin type of Providence.

Lysogeny and bacteriocinogeny appear to be an extremely common phenomenon in this group of bacteria, and it is possible that a typing system for this organism could be established by refining and extending the system used in this study.

The results of the MIC screening on the 31 strains of Providence and the control organisms, E. coli 10418 and $P$. mirabilis 61 , presented in figs 1 and 2 , show that this organism can be even more resistant to cationic antiseptics than the strains of $P$. mirabilis reported as chlorhexidine resistant (Stickler, 1974). The majority of the strains in this study had MICs for chlorhexidine over 300 -fold higher than that of the control $E$. coli strain. They are similarly considerably more resistant to cetrimide and Resiguard. In the cases of Hycolin, glutaraldehyde, and phenyl mercuric nitrate, however, the MICs of the Providence strains are similar to those of the control strain.

It is quite likely that the levels recorded for the MIC of glutaraldehyde are all raised due to the inactivation of this agent by the peptones present in nutrient agar (Russell and Munton, 1974).

Examination of the MIC data for the Providence strains strongly suggested a correlation between the degree of resistance to the various cationic agents. Fig. 3 shows the relationship obtained when the MIC values for Resiguard for each strain are plotted against those for cetrimide and Hycolin. The Kendal and Spearman rank correlation coefficients (table IV) show that there were highly significant correlations (the probability that such values for the correlation coefficients could be due to chance being $P<0.001$ ) between the resistance of the strains to the three cationic antiseptics. There were no such highly 
significant correlations between the cationic agents and any of the other three antibacterials.

The tests for bactericidal activity (table V) also show this pattern. The data presented in this table were analysed for differences between mean log reduction in counts by one-way analysis of variance and the sum of squares simultaneous test procedure (Gabriel, 1964). It was found that within the group S or group $R$ there were no significant differences between the means of the log reduction values. However, there was a highly significant difference $(\mathbf{P}<$ 0.001 ) between the log reductions of the two groups for chlorhexidine, cetrimide, and Resiguard. For Betadine, Hycolin, and hypochlorite there was no significant difference in the mean values for the two groups.

The results of the MIC determinations on the chlorhexidine-sensitive mutants of Providence strain 66 (table VI) indicate that loss of chlorhexidine resistance is accompanied by loss of resistance to cetrimide and Resiguard but results in no substantial difference in sensitivity to the other three agents.

In summary, it appears that the results from the MIC determinations, the tests for bactericidal activity, and the examination of the properties of chlorhexidine-sensitive mutants, all indicate the existence of cross-resistance to cationic antiseptics in strains of Providence. The resistances of these strains to the cationic antiseptics were of course registered in laboratory tests which do not adequately reflect the conditions under which the antiseptics are required to work in practice. However, as many of these strains were isolated from situations in which antiseptics are extensively employed, it is not unreasonable to suppose that the levels of resistance recorded in the MIC and bactericidal tests are significant and reflect an enhanced ability of these organisms to survive in the hospital environment.

Resistance to quaternary ammonium compounds has been reported in E. coli (Chaplin, 1951), Serratia marcescens (Chaplin, 1952), and Ps. aeruginosa (MacGregor and Elliker, 1958; Adair et al, 1971), and resistance to chlorhexidine in Ps. aeruginosa (Bentley et al, 1968) and P. mirabilis (Stickler, 1974). In a number of these cases the resistance has been attributed to changes in the chemical structure of the Gram-negative envelope (Davies and Roberts, 1969; Anderes et al, 1971), which prevent the adsorption of the cationic agents onto the underlying membrane, where they are believed to exert their antibacterial effect (Hugo, 1967; Davies and Field, 1969). It is possible that the cell envelope of Providence has a structure that protects the cytoplasmic membrane from disruption by cationic antiseptics and results in a level of intrinsic resistance to these agents.
In conclusion, it seems that Providence B (Pro- $\frac{0}{\overrightarrow{5}}$ videncia stuartii) is an organism extremely well $\underline{\underline{0}}$ equipped to survive in the hospital environment, being not only multiply antibiotic resistant but also $\stackrel{\vec{F}}{\rightarrow}$ having a degree of resistance to a number of extensively used antiseptics.

We are grateful to Dr J. M. H. Boyce and the tech- $\stackrel{\varnothing}{\square}$ nical staffs of the bacteriological laboratories at St. œ David's and the University of Wales Hospitals, $\overrightarrow{0}$ Cardiff, for supplying many of the strains used in this study. We should like to acknowledge the technical $\vec{\omega}$ assistance of Mr J. McCormick in part of this work, and we are indebted to the Welsh Medical Research ? Advisory Committee for financial support.

\section{References}

Adair, F. W., Geftic, S. G., and Gelzer, J. (1971). Resistance $\vec{\oplus}$ of Pseudomonas to quaternary ammonium compounds. II. $\mathbb{D}$ Cross-resistance characteristics of a mutant of Pseudo- $\frac{D}{D}$ monas aeruginosa. Appl. Microbiol., 21, 1058-1063.

Adelberg, E. A., Mandel, M., and Chen, G. C. C. (1965) Optimal conditions for mutagenesis by $N$-methyl- $N^{\prime}$-nitro$N$-nitrosoguanidine in Escherichia coli $\mathrm{K} 12$. Biochem. biophys. Res. Commun., 18, 788-795.

Anderes, E. A., Sandine, W. E., and Elliker, P. R., (19710 Lipids of antibiotic-sensitive and -resistant strains Pseudomonas aeruginosa. Canad. J. Microbiol., 17, 13倝 1365.

Bentley, M., Davies, A., Field, B. S., and Roberts, W. (1968). Characteristics of growth of a Pseudomonas species in culture media containing chlorhexidine. Biochem. J., 110, $46 \mathrm{p}$.

Chaplin, C. E. (1951). Observations on quaternary ammonium disinfectants. Canad. J. Bot., 29, 373-382.

Chaplin, C. E. (1952). Bacterial resistance to quaternary ammonium disinfectants. J. Bact., 63, 453-458.

Cowan, S. T. and Steel, K. J. (1965). Manual for the Identification of Medical Bacteria. Cambridge University Press, Cambridge.

Davies, A. and Field, B. S. (1969). Action of biguanides, $\frac{0}{3}$ phenols and detergents on Escherichia coli and its spheroplasts. J. appl. Bact., 32, 233-243.

Davies, A. and Roberts, W. (1969). The cell wall of a chlor- $\frac{O}{3}$ hexidine-resistant Pseudomonas. Biochem. J., 112, 15p.

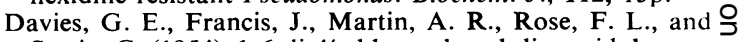
Swain, G. (1954). 1 :6-di-4'-chloro-phenyl-diguanidohexane $D$ (Hibitane). Laboratory investigation of a new antibacterial agent of high potency. Brit. J. Pharmacol., 9, 192-196.

Desautels, R. E. (1969). The causes of catheter-induced $N$ urinary infections and their prevention. J. Urol., 101, 757760.

Dobrey, R. (1971). A hospital study of the Providence group, N with particular reference to subgrouping and the possible $\omega$ presence of R. factors. Canad.J. med. Technol., 33, 177-187.

Dutton, A. A. C. and Ralston, M. (1957). Urinary tract in-e fection in a male urological ward. Lancet, 1, 115-119.

Edwards, P. R. and Ewing, W. H. (1972). Identification of $\$$ Enterobacteriaceae, 3 rd edition. Burgess, Minneapolis.

Ewing, W. H., Tanner, K. E., and Dennard, D. A. (1954). T The Providence group: an intermediate group of enteric bacteria. J. infect. Dis., 94, 134-140. 
Farmer, J. J. 3rd, and Herman, L. G. (1969). Epidemiological fingerprinting of Pseudomonas aeruginosa by the production of and sensitivity of pyocin and bacteriophage. Appl. Microbiol., 18, 760-765.

Fields, B. N., Uwaydah, M. M., Kunz, L. J., and Swartz, M. N. (1967). The so-called "Paracolon" bacteria: a bacteriologic and clinical re-appraisal. Amer. J. Med., 42 , 89-106.

Gabriel, K. R. (1964). A procedure for testing the homogeneity of all sets of means in analysis of variance. Biometrics, 20, 459-477.

Gillespie, W. A., Lennon, G. G., Linton, K. B., and Phippen, G. A. (1967). Prevention of urinary infection by means of closed drainage into a sterile plastic bag. Brit. med. J., 3 90-92.

Graevenitz, A. von and Nourbakhsh, M. (1972). Antimicrobial resistance of the genera Proteus, Providencia and Serratia with special reference to multiple resistance patterns. Med. Microbiol. Immunol., 157, 142-148.

Hugo, W. B. (1967). The mode of action of antibacterial agents. J. appl. Bact., 30, 17-50.

Kelsey, J. C. and Maurer, I. M. (1972). The Use of Chemical Disinfectants in Hospitals (Public Health Laboratory Service, Monograph Series, No. 2). HMSO, London.

Li, K. and Miller, C. (1970). Pathogenic bacteria and their sensitivity patterns in a hospital population of geriatric patients with chronic disease. J. Amer. Geriat. Soc., 18 286-294.

MacGregor, D. R. and Elliker, P. R. (1958). A comparison of some properties of strains of Pseudomonas aeruginosa sensitive and resistant to quaternary ammonium compounds. Canad. J. Microbiol., 4, 499-503.

Middleton, J. E. (1958). The sensitivity in vitro of the Providence group of enteric bacteria to fourteen antibiotics and nitrofurantoin. J. clin. Path., 11, 270-272.

Milner, P.F.(1963). The differentiation of Enterobacteriaceae infecting the urinary tract: a study in male paraplegics. J. clin. Path., 16, 39-45.

Nie, N. H., Bent, D. H., and Hull, C. H. (1970). Statistical Package for the Social Sciences. McGraw-Hill, New York.

O'Flynn, J. D. and Stickler, D. J. (1972). Disinfectants and Gram-negative bacteria. Lancet, 1, 489-490.

Otsuji, N., Sekiguchi, M., Iijima, T., and Takagi, Y. (1959). Induction of phage formation in the lysogenic Escherichia coli $\mathrm{K}-12$ by mitomycin-c. Nature (Lond.), 184, 1079-1080.

Overturf, G. D., Wilkins, J., and Ressler, R. (1974). Emergence of resistance of Providencia stuartii to multiple antibiotics: speciation and biochemical characterization of Providencia. J. infect. Dis., 129, 353-357.

Russell, A. D. (1974). Factors influencing the activity of antimicrobial agents: an appraisal. Microbios., 10, 151-174.

Russell, A. D. and Munton, T. J. (1974). Bactericidal and bacteriostatic activity of glutaraldehyde and its interaction with lysine and proteins. Microbios, 11, 147-152.

Solberg, C. O. and Matsen, J. M. (1971). Infections with Providence bacilli: a clinical and bacteriological study. Amer. J. Med., 50, 241-246.

Stickler, D. J. (1974). Chlorhexidine resistance in Proteus mirabilis. J. clin. Path., 27, 284-287.

Stickler, D. J., Wilmot, C. B., and O'Flynn, J. D. (1971) The mode of development of urinary infection in intermittently catheterized male paraplegics. Paraplegia, 8, 243. 252.

Tarr, H. A. (1958). Mechanical aids for the phage-typing of Staphylococcus aureus. Mth. Bull. Minist. Hlth. Lab. Serv., 17, 64-72.

Tomaschoff, E. (1969). Die Ökologie und Bedeutung der Proteusgruppe. Klin. Wschr., 47, 837-844. 